\title{
PENINGKATAN KEMAMPUAN MERANCANG PEMBUKTIAN HIPOTESIS DALAM PEMBELAJARAN MENGGUNAKAN PENDEKATAN SAINTIFIK DENGAN PEMBERIAN TUGAS AWAL
}

\author{
${ }^{1}$ Universitas Pendidikan Ganesha \\ 2Universitas Pendidikan Ganesha \\ 3SMA Negeri 1 Singaraja
}

Diani Rachmanita Murniati'*, Ida Bagus Nyoman Sudria ${ }^{2}$, I Ketut Kariada 3

\begin{abstract}
Abstrak
Hasil observasi awal menunjukkan menunjukan penerapan pendekatan saintifik memiliki kendala yaitu pelaksanaan 5-M tentang keterbatasan waktu. Siswa mengalami kendala dalam tahapan mengamati (untuk mengidentifikasi atau menemukan masalah) dikarenakan membutuhkan waktu yang cukup lama untuk mengamati fenomena yang dikemas secara kontekstual. Selain itu kendala yang dihadapi siswa adalah tahap menanya yang masih rendah dan pertanyaan yang tidak terarah (diluar lingkup kajian yang akan dipelajari). Selain itu dalam menerapkan metode ilmiah di LKS sebelumnya belum nampak kegiatan 5-M. Hal ini tentu harus dilatihkan dan diperbaikivagar siswa mampu menggunakan metode ilmiah dalam mempelajari setiap konsep. Tujuan penelitian ini adalah Untuk meningkatkan kemampuan siswa kelas XI MIPA 3 SMA Negeri 1 Singaraja tahun ajaran 2016/2017 dalam membuat rancangan pembuktian hipotesis.

Jenis penelitian yang digunakan adalah penelitian tindakan kelas yang terdiri dari 4 siklus. Penelitian ini dilaksanakan di SMA Negeri 1 Singaraja dengan subjek penelitian siswa kelas XI MIPA 3 dengan jumlah 30 siswa. Data penelitian ini adalah draf rancangan pembuktian hipotesisi dari siswa. Instrumen penelitian yang digunakan adalah lembar observasi untuk mengukur kemampuan siswa dalam membuat draf pengamatan awal, rumusan masalah, hipotesis dan rancangan pembuktian. Data dianalisis dengan menghitung jumlah siswa yang telah mampu mempuat draf rancangan sesuai dengan harapan minimal peneliti. Tahap terakhir adalah tahap refleksi untuk menentukan inovasi perlakuan dan lanjut atau tidaknya penelitian.

Hasil analisis data pada siklus I dan siklus II bahwa pemberian tugas awal dapat meningkatkan kemampuan siswa dalam membuat mengamati fenomena sebesar 33,34\%, dari siklus II ke siklus III mengalami penurunan 3,34\%, dari siklus III ke siklus IV mengalami penurunan $6,66 \%$. Kegiatan siswa dalam dalam merumuskan masalah mengalami peningkatan $26 \%$ dari siklus I ke siklus II, dari siklus II ke siklus III mengalami penurunan $46,67 \%$ dan mengalami peningkatan dari siklus III ke siklus IV 26\%. Kemampuan siswa dalam membuat hipotesis mengalami peningkatan 20,67\% dari siklus I ke siklus II, sedangkan siklus II ke siklus III mengalami penurunan $46,67 \%$ dan meningkat pada siklus IV sebesar $26 \%$. Kemampuan siswa dalam membuat variabel mengalami peningkatan dari siklus I ke siklus II sebesar 13,33\%, mengalami penurunan dari siklus II ke siklus III 10\% dan penurunan dari siklus III ke siklus IV 41,33\%. Kegiatan siswa dalam mendesain percobaan dari siklus I ke siklus II mengalami peningkatan 94,67\% dari siklus I ke siklus II sedangkan siklus III dan IV mengalami penurunan 94,67\%. Kemampuan siswa dalam menentukan alat dan bahan mengalami peningkatan $26,57 \%$ dari siklus I ke siklus II, mengalami peningkatan 40,66\% dari siklus II ke siklus III dan mengalami penurunan $67,33 \%$ pada siklus IV. Kegiatan siswa dalam menyusun prosedur kerja mengalami peningkatan dari siklus I ke siklus II sebesar $66 \%$. Dari siklus II ke siklus III mengalami penurunan $12,67 \%$ dan penurunan $53,33 \%$ pada siklus IV.
\end{abstract}

\author{
Kata-kata kunci: \\ mind mapping, aktivitas \\ belajar, dan hasil belajar.
}




\section{Pendahuluan}

Pembelajaran sain di sekolah diharapkan menjadi wahana bagi siswa untuk mempelajari dan mengembangkan kompetensi diri sera memahami alam sekitar secara ilmiah. Ilmu kimia yang merupakan salah satu bidang ilmu dalam sains yang mempelajari sifat, struktur, komposisi dan perubahan materi serta energi yang menyertainya memiliki fungsi sebagai wahana pengembangan ketrampilan intelektual, kreatifitas, dan sikap ilmiah. Seiring dengan diterapkannya Kurikulum 2013, yang menekankan pada penerapan pendekatan saintifik yang tertulis pada Permendikbud No. 65 Tahun 2013 tentang Standar Proses Pendidikan Dasar dan Menengah yang telah mengisyaratkan tentang perlunya proses pembelajaran yang dipandu dengan kaidahkaidah pendekatan saintifik/ilmiah.

Pendekatan saintifik merupakan pembelajaran yang mengadopsi langkah-langkah saintis dalam membangun pengetahuan melalui metode ilmiah. Penerapan Pendekatan saintifik/ilmiah dalam proses pembelajaran ini akan menghasilkan pembelajaran yang lebih bermakna bila diterapkan dalam pembelajaran secara terpadu. Dalam proses pembelajaran dirancang sedemikian rupa agar siswa secara aktif mengonstruk konsep, hukum atau prinsip melalui tahapan-tahapan mengamati (untuk mengidentifikasi atau menemukan masalah), merumuskan masalah, mengajukan atau merumuskan hipotesis, mengumpulkan data dengan berbagai teknik, menganalisis data, menarik kesimpulan dan mengomunikasikan konsep, hukum atau prinsip yang "ditemukan".

Teori konstruktivisme menyatakan bahwa dalam proses belajar, siswa harus membangun sendiri konsepsi secara aktif dan mandiri (Iskandar, 2004). Siswa mengkonstruksi/membangun pemahaman mereka sendiri dari pengalaman baru berdasar pada pengetahuan awal melalui proses interaksi sosial dan asimilasi-akomodasi. Implikasinya adalah pembelajaran harus dikemas menjadi proses "mengkonstruksi" bukan menerima pengetahuan.

Berdasarkan hasil observasi awal di kelas XI MIA 3 menunjukan penerapan pendekatan saintifik memiliki kendala yaitu pelaksanaan 5-M tentang keterbatasan waktu. Siswa mengalami kendala dalam tahapan mengamati (untuk mengidentifikasi atau menemukan masalah) dikarenakan membutuhkan waktu yang cukup lama untuk mengamati fenomena yang dikemas secara kontekstual. Selain itu kendala yang dihadapi siswa adalah tahap menanya yang masih rendah dan pertanyaan yang tidak terarah (diluar lingkup kajian yang akan dipelajari). Keberhasilan pada tahap menanya adalah siswa mampu mengamati fenomena secara seksama. Fenomena harus mampu mengakomodasi pengetahuan siswa dalam bentuk fakta, konsep, prinsip, prosedur, hukum dan terori. Tindak lanjut kegiatan bertanya adalah menggali dan mengumpulkan informasi dari berbagai sumber melalui berbagai cara dengan membaca buku, memperhatikan fenomena, atau objek dengan lebih teliti.

Selain masalah keterbatasan waktu, saat peneliti mencoba untuk menugaskan siswa membuat draf rancangan pembuktian hipotesis seacara untuh. Ternyata sebagian besar siswa belum mahir mengidentifikasi variabel, membuat desain pembuktian, mengidentifikasi alat/bahan dan menyusun prosedur kerja. Hal ini tentu harus ditingkatkan agar siswa mampu menggunakan metode ilmiah dalam mempelajari setiap konsep. Sehingga siswa mempunyai sikap sains yang baik dalam mempelajari ilmu kimia sebagai suatu proses sains.

Berdasarkan uraian di atas, perlu dilakukan penelitian untuk meningkatkan kemampuan siswa dalam membuat rancangan pembuktian hipotesis secara mandiri.untuk mengatasi kekurangan waktu maka diperlukan penugasan awal sebelum kegiatan pembelajaran. Oleh karena itu, peneliti terdorong untuk melakukan penelitian dengan judul "Peningkatan Kemampuan Merancang Pembuktian Hipotesis dalam Pembelajaran Menggunakan Pendekatan Saintifik dengan Pemberian Tugas Awal pada Siswa Kelas XI-MIA 3 SMAN 1 Singaraja Tahun Ajaran 2016/2017."

\section{Metode}

Penelitian ini merupakan penelitian tindakan kelas (Classroom Action Research) model Kemmis dan M.C. Taggart. Penelitian ini menggunakan pendekatan kualitatif karena sumber data langsung berasal dari permasalahan yang dihadapi guru atau peneliti dan data deskriptif berupa kata-kata atau kalimat. Penelitian ini dilaksankan dalam empat siklus. Penelitian tindakan kelas ini diprediksi dilakuakn dalam lima siklus. Desain penelitian yang digunakan mengacu pada model Kemmis dan M.C.Taggart (1988) yang terdiri dari: (1)Perencanaan, Pada tahap perencanaan ini dilakukan persiapan yang berhubungan dengan pelaksanaan pembelajaran dengan pendekatan saintifik, seperti identifikasi masalah, pembuatan rencana pembelajaran, pembuatan lembar kerja siswa, pembuatan lembar pengamatan siswa dan guru, penyediaan alat dan media yang akan digunakan. (2) Tindakan 
dan observasi Pelaksanaan tindakan merupakan kegiatan dilaksanakannya skenario pembelajaran yang telah direncanakan. Adapun tindakan yang dilakukan oleh guru adalah memberi tugas membuat draf rancangan pembuktian hipotetsis secara mandiri kepada siswa pada pertemuan sebelumnya, membimbing siswa dalam diskusi, serta memberikan tes di akhir siklus. Tindakan yang juga dilakukan guru adalah menilai rancangan eksperimen yang telah disusun oleh siswa, mengobservasi kegiatan siswa selama mengikuti pembelajaran seperti diskusi, dan mempresentasikan hasil diskusi. (3),Refleksi berkenaan dengan proses dan dampak yang akan dilakukan. Dengan data observasi, guru dapat merefleksi diri apakah pembelajaran yang telah berhasil meningkatkan kemampuan siswa dalam merancang pembuktian hipotesis. Hasil dari refleksi adalah diadakannya perbaikan terhadap perencanaan yang telah dilaksanakan dan perbaikan pada LKS yang akan digunakan untuk memperbaiki kinerja guru pada siklus selanjutnya. Refleksi berkenaan dengan proses dan dampak yang akan dilakukan.Hasil dari refleksi adalah diadakannya perbaikan terhadap perencanaan yang telah dilaksanakan, yang akan digunakan untuk memperbaiki kinerja guru pada siklus selanjutnya. Prosedur dan langkahlangkah yang digunakan dalam melaksanakan penelitian ini menggunakan sistem spiral refleksi diri yang dimulai dengan rencana tindakan (planning), tindakan (acting), pengamatan (observing) dan refleksi (reflecting). Kegiatan ini disebut dengan satu siklus (Arikunto, Suhardjono, Supardi, 2006:16). Siklus akan berakhir jika hasil penelitian yang diperoleh telah memenuhi indikator keberhasilan yang ditetapkan. Seperti yang disajikan pada gambar 1 berikut.

Teknik pengumpulan data pada penelitian ini adalah observasi terhadap rancangan pembuktian hipotesis. Observasi dilakukan untuk mengetahui kemampuan siswa dalam merancang hipotesis. Instrumen yang digunakan dalam penelitian ini meliputi: (1) lembar penilaian rancangan pembuktian hipotesis. Data-data dari hasil penelitian (observasi) di lapangan diolah dan dianalisis secara deskriptif kualitatif. Penelitian tindakan kelas ini dikatakan berhasil apabila terjadi peningkatan kemampuan merancang pembuktian hipotesis siswa secara klasikal/ maupun individual. Pada penelitian ini digunakan analisis deskriptif dengan membandingkan kemampuan mmerancang eksperimen atau pembuktian hipotetsis sebelum dan sesudah tindakan. Data berupa hasil hasil observasi, dan angket tindakan. Langkah- langkah sebagai berikut: (1), Merekapitulasi hasil observasi terhadap rancangan eksperimen atau pembuktian hipotesis siswa sebelum tindakan. (2), Merekapitulasi hasil observasi rancangan eksperimen atau pembuktian hipotesis siswa setelah tindakan. (3), Mengitung rata-rata capaian siswa. (4), Merekapitulasi hasil angket tentang penguasaan merancang eksperimen atau pembuktian hipotesis siswa setelah tindakan. (5), Membandingkan hasil observasi dan angket untuk mengetahui peningkatan kemampuan merancang eksperimen atau pembuktian hipotesis siswa.

Penelitian ini dikatakan berhasil apabila ada peningkatan jumlah siswa yang mampu membuat rancangan pembuktian hipotesis sesuai harapan minimal peneliti, atau ada peningkatan rata-rata capaian siswa pada setiap komponen rancangan.

\section{Hasil}

Sesuai dengan penelitian yang telah disampaikan pada bab sebelumnya, penelitian ini meruakan Penelitian Tindakan Kelas (PTK) dengan tujuan meningkatkan kemampuan siswa kelas XI MIA 3 SMA Negeri 1 Singararaja tahun ajaran 2016/2017 dalam membuat rancangan pembuktian hipotesis. Kelas XI-MIA 3 terdiri dari 30 siswa dengan jumlah laki-laki 18 orang dan perempuan 12 orang. Observasi awal dilakukan pada saat pengajaran materi termokimia Observasi dilakukan di dalam kelas dan di laboratorium saat percobaan kalorimeter. Pada saat percobaan ini,peneliti tidak meminta siswa untuk merancang eksperimen sendiri. Tetapi guru langsung memberikan demonstrasi dan meminta siswa menuliskan langkah-langkah percobaannya setelah demontrasi. Observasi berikutnya berlangsung saat pembelajaran di kelas. Dari hasil observasi diketahui bahwa siswa masih mengalami kesulitan melakukan observasi awal terhadap fenomena. Kendala tersebut dikarenakan keterbatasan dalam memahami isi dari sebuah fenomena, merumuskan pertanyaan berdasarkan fenomena yang diamati, membuat hipotesis dan merancang sehingga dalam kegiatan pembelajaran di kelas untuk keterlaksanaan 5M dirasa kurang maksimal. Hal tersebut juga didukung dari kurang siapnya siswa dalam kegiatan pembelajaran seperti mempersiapkan diri sebelum pembelajaran. Kegiatan yang dilakukan pada siklus I meliputi tahap perencanaan tindakan, tahap pelaksanaan tindakan, tahap observasi tindakan, dan tahap refleksi tindakan. Data yang diperoleh masingmasing tahap adalah sebagai berikut. (1), Perencanaan I Berdasarkan hasil observasi awal kemudian disusun rencana tindakan 
pembelajaran menggunakan pendekatan saintifik. Pada tahap ini peneliti membuat perangkat pembelajaran dengan model 5M meningkatkan kemampuan siswa kelas XI MIA 3 dalam merancang pembuktian hipotesis. Peneliti menyiapkan LKS yang mengakomodasi kegiatan 5M. Peneliti juga menyiapkan rubrik penilaian kemampuan merancang pembuktian hipotesis. Materi yang digunakan adalah pengertian laju reaksi, defnisi laju rata-rata dan laju sesaat. Proses pembelajaran pada siklus I ini dilaksanakan selama 2 x 45 menit yang dilaksanakan pada Senin, 19 September 2016 . (2) Implementasi Tindakan I Pada tahap ini peneliti melaksanakan pembelajaran model 5M sesuai dengan perangkat pembelajaran yang telah dibuat. Kegiatan merancang pembuktian telah ditugaskan secara individu pada pertemuan sebelumnya dan peneliti melakukan penilaian dari hasil tugas tersebut sebelum kegiatan pembelajaran berlangsung. Peneliti juga menggali pertanyaan yang dimiliki siswa ketika mengamati sebuah fenomena yang telah disajikan. Pada awal pembelajaran peneliti bersama-sama siswa mendiskusikan rancangan pembuktian hipotesis dan menyepakati rancangan yang akan digunakan dalam pembelajaran Selain itu peneliti masih memberikan bimbingan dalam menentukan desain pembuktian hipotesis dan menentukaan variabel-variabel yang terlibat. Fenomena yang disajikan pada kegiatan pertama menggunakan pendekatan induktif selanjutnya mengumpulkan data dibantu oleh program interaktif laju reaksi berbantuan komputer yang meliputi pengertian laju reaksi, laju rata-rata dan laju sesaat yang telah dibagikan sebelumnya oleh siswa untuk mengamati di rumah. Sebagai pengatar awal materi pada laju reaksi, hendaknya dilakukan secara eksperimen secara langsung agar termotivasi, hal tersebut telah disajikan dalam media interaktif laju reaksi dengan menyajikan eksperimen laboratorium di awal pembelajaran. Program interaktif berperan memberikan pendalaman dan penguatan konsepsi yang dibangun berdasarkan data hasil eksperimen

Salah satu media visual yang dapat digunakan untuk menjelaskan konsep tersebut adalah grafik. Grafik merupakan pemaparan visual yang menghubungan dua sifat. Tiap titik pada grafik memberikan suatu nilai untuk suatu sifat dan nilai lain untuk sifat lainnya. Grafik dapat dibentuk dari data yang diperoleh dari hasil eksperimen, sehingga hubungan antar data dapat dipahami dengan mudah siswa dalam memahami laju rata-rata dan laju sesaat .

Pada akhir pertemuan meminta siswa untuk membuat sendiri rancangan pembuktian hipotesis secara mandiri dan dikumpulkan sebelum kegiatan pembelajaran. Berdasarkan hasil observasi diketahui bahwa pada siklus IV ini tidak adanya peningkatan pada desain percobaan. Seluruh siswa mengalami kesulitan dalam membuat desain percobaan secara mandiri dalam pembuktian hipotesis. Mereka lebih senang dibimbing dan dijelaskan secara langsung karena tidak memiliki gambaran untuk membuktikan walaupun telah disajikan media interaktif berbasis komputer. Hal ini juga didukung dengan menurunnya siswa dalam mengidentifikasi variabel. Kesulitan ini dikarenakan siswa lebih sulit untuk membuat variabel dari kegiatan pembelajaran non eksperiment seperti siklus I yang memiliki kendala yang sama. hal ini berbeda pada siklus II yang mengalami peningkatan karena kegiatan pembelajaran secara eksperimen. Sehingga perlunya bimbingan secara intensif dan siswa perlu banyak latihan agar tebiasa membuat desain percobaan secara mandiri.

\section{Pembahasan}

Penelitian tindakan kelas bertujuan untuk memperbaiki dan meningkatkan ketrampilan proses ilmiah siswa. Kegiatan pada siklus I-IV terdapat kegiatan eksperimen dan non eksperimen. Pada kegiatan pembelajaran yang bersifat eksperimen, ketrampilan proses ilmiah siswa sangat baik yang dapat dilihat pada grafik di gambar 4.2. Hal ini dikarenakan siswa terlatih bersikap ilmiah pada kegiatan praktikum sejak duduk di SMP terutama mata pelajaran IPA. Pengenalan membuat hipotesis, menentukan variabel, hingga menentukan alat dan bahan telah diperkenalkan kepada siswa sejak duduk di bangku SMP. Namun hal ini justru sebaliknya pada kegiatan non eksperimen, hal ini terasa baru bagi siswa saat menentukan variabel hingga prosedur kerja. Faktor tersebut dikarenakan guru menyajikan fenomena secara klasikal, tidak adanya perangkat LKS yang dibuat oleh guru dan siswa cenderung tidak menemukan konsep karena konsep telah diberikan oleh guru. Sehingga membuat siswa cenderung menggunakan metode hapalan yang berdampak pada diri siswa. Peneliti berusaha melatihkan siswa agar terbiasa bekerja secara proses ilmiah meskipun disadari peneliti juga masih banyak kekurangan dalam melatihkan siswa. (1), Pada kegiatan siklus II siswa dihadapkan langsung dengan kegiatan praktikum atau eksperimen, sedangkan pada siklus I, III dan IV merupakan kegiatan non eksperimen. (2), Kegiatan pengamatan awal terjadi peningkatan keterampilan proses ilmiah.Siswa mampu menulis poin-poin penting dalam fenomena yang telah disajikan dikarenakan peneliti menekankan poin-poin 
penting dari bacaan yang diamati agar dituliskan. Pada siklus I dan siklus II bahwa pemberian tugas awal dapat meningkatkan kemampuan siswa dalam membuat mengamati fenomena sebesar 33,34\%, dari siklus II ke siklus III mengalami penurunan 3,34\%, dari siklus III ke siklus IV mengalami penurunan 6,66\%. (3), Kegiatan merumuskan masalah juga mengalami peningkatan, namun peneliti tidak begitu yakin pada jawaban siswa apakah pertanyaan itu berdasarakan pertanyaan yang muncul dari benak siswa atau semata hanya melihat tujuan kegiatan. Siswa melihat tujuan pembelajaran di LKS sehingga dapat mengetahui harapan pertanyaan yang muncul harus sesuai dengan tujuan pembelajaran. Kegiatan siswa dalam dalam merumuskan masalah mengalami peningkatan $26 \%$ dari siklus I ke siklus II, dari siklus II ke siklus III mengalami penurunan $46,67 \%$ dan mengalami peningkatan dari siklus III ke siklus IV 26\%. (4), Merumuskan hipotesis pada siklus III mengalami penurunan disebabkan kurangnya membaca buku dari literatur yang telah disediakan. Kemampuan siswa dalam membuat hipotesis mengalami peningkatan $20,67 \%$ dari siklus I ke siklus II, sedangkan siklus II ke siklus III mengalami penurunan $46,67 \%$ dan meningkat kembali pada siklus IV sebesar 26\%. (5), Kegiatan siswa dalam mengidentifikasikan variabel terjadi penurunan yang sangat signifikan anatara siklus I hingga siklus IV dikarenakan siswa masih belum terampil membuat variabel berdasarkan data non eksperimen secara mandiri. Siswa membutuhkan bimbingan saat pembuatan variabel. Meskipun pada siklus III siswa dapat membuat variabel dari data non eksperimen dibandingkan siklus I. Hal ini disebabkan dengan bantuan grafik siswa mampu merumuskan korelasinya yang telah dilatihkan pada saat memperhatikan grafik laju reaksi pada siklus I. Kemampuan siswa dalam membuat variabel mengalami peningkatan dari siklus I ke siklus II sebesar 13,33\%, mengalami penurunan dari siklus II ke siklus III 10\% dan penurunan dari siklus III ke siklus IV 41,33\%. (6), Kegiatan membuat desain pembuktian, siswa lebih mampu membuat desain pembuktian pada materi yang bersifat eksperimen (Siklus II) dibandingkan non eksperimen (siklus I,III dan IV). Kegiatan siswa dalam mendesain percobaan dari siklus I ke siklus II mengalami peningkatan 94,67\% sedangkan siklus II hingga IV mengalami penurunan 94,67\%. (7), Pada Kegiatan mengidentifikasi alat dan bahan siswa mengalami kesulitan pada siklus II karena tidak terlalu spesifik penyebutan alat bahan, sedangkan pada siklus III mengalami kenaikan karena mereka hanya menyalin jawaban dari siklus II yang telah dikoreksi bersama. Pada kegiatan menyusun prosedur kerja terdapat siswa yang tidak melengkapi dengan baik dikarenakan pada saat siklus II dan III hanya berselang satu hari dalam kegiatan. Kemampuan siswa dalam menentukan alat dan bahan mengalami peningkatan $26,57 \%$ dari siklus I ke siklus II, mengalami peningkatan 40,66\% dari siklus II ke siklus III dan mengalami penurunan $67,33 \%$ pada siklus IV. (8), Kegiatan siswa dalam menyusun prosedur kerja mengalami peningkatan dari siklus I ke siklus II sebesar $66 \%$ dikarenakan kegiatan adalah eksperimen. Pada siklus II ke siklus III mengalami penurunan $12,67 \%$ dan penurunan $53,33 \%$ pada siklus IV.

\section{Simpulan}

Berdasarkan paparan data dan pembahasan tentang peningkatan kemampuan merancang pembuktian hipotesis dalam pembelajaran menggunakan pendekatan saintifik pada siswa kelas XI MIA 3 SMA Negeri 1 dapat disimpulkan bahwa penugasan awal membuat draf pengamatan awal, rumusan masalah, hipotetsis dan rancangan pembuktian hipotetsis dapat meningkatkan kemampuan siswa dalam merancang pembuktian hipotesis baik eksperimen. Untuk kegiatan non eksperimen masih diperlukan bimbingan khusus secara berkelanjutan agar siswa terlatih secara mandiri tanpa memerlukan bimbingan

\section{Daftar Pustaka}

Arikunto Suharsimi, Suhardjono, Supardi.2016. Penelitian Tindakan Kelas.Jakarta : Bumi Aksara. Baldwin, A.L.1967. Theories of Child Development. New York:John Wiley \& Sons.

Carin, A.A. \& Sund, R,B. 1975. Teaching Sience though Discovery, 3rd Ed. Colombus: Charles E. Merrill Publishing Company

Chittleborough, G.D. 2004. The Role of Teaching Models and Chemical Representations in Developing Mental Models of Chemical Phenomena. Thesis. Science and Mathematics Education Centre.

Fauziah, R. et al. 2013. Pembelajaran Saintifik Elektronika Dasar Berorientasi Pembelajaran Berbasis Masalah. Jurnal Invotec., 9(2): 165-178

Kemendikbud.2013. Pengembangan Kurikulum 2013. Paparan mendikbud dalam sosialisasi

kurikulum.jakarta:Kemendikbud

Paidi.2013. Peningkatan Kompetensi Calon Guru IPA melalui Pengembangan 
Keterampilan Proses Sains dalam Pengajaran Mikro. Prosiding SeminarNasional Hasil Penelitian MIPA dan Pendidikan MIPA, diselenggarakan oleh FMIPA UNY di Hotel Sahid Raya Yogyakarta, 28 Juni 2003.

Sastrawijaya, Tresna. 1988. Proses Belajar Mengajar Kimia. Jakarta: Depdikbud Dirjen Dikti PPLPTK.

Sudria, dkk. 2011. Pengaruh Pembelajaran Interaktif Laju Reaksi Berbantuan Komputer Terhadap Hasil Belajar Siswa. Jurnal Pendidikan dan Pengajaran, 44(1-3): 25-33. 